\title{
Awkward defects around the elbow: The radial recurrent artery flap revisited
}

\author{
Maksud M. Devale, Rohit P. Munot, Chirag A. Bhansali, Neeraj D. Bhaban \\ Department of Plastic Surgery, Lokmanya Tilak Municipal Medical College, Mumbai, Maharashtra, India
}

Address for correspondence: Dr. Rohit P. Munot, Department of Plastic Surgery, Room No 450, $4^{\text {th }}$ Floor College Building, Lokmanya Tilak Municipal Medical College, Sion, Mumbai - 400 022, Maharashtra, India. E-mail: rohitmunot@gmail.com

\section{ABSTRACT}

Background: Soft tissue defects on the posterior aspect of the elbow are commonly seen in patients treated with internal fixation for fractures around the elbow joint. An axial flap based on the radial recurrent artery (RRA) is very useful for such defects, especially if a posterior midline arm incision has been taken for skeletal fixation. The aim of this study is to describe the usefulness of RRA flap (based on the RRA) in the management of such defects. Materials and Methods: We present a retrospective analysis of 4 cases managed with the RRA flap for soft tissue reconstruction of defects around the elbow joint at our institute from January 2015 to August 2016. All the patients were males with a history of exposed implant following internal fixation of olecranon/distal humerus fracture. The size of defects ranged from $4 \mathrm{~cm} \times 4 \mathrm{~cm}$ to $7 \mathrm{~cm} \times 5 \mathrm{~cm}$. Results of the analysis are presented here. Results: All flaps survived completely. There was no infection, hematoma or distal neurovascular deficit. There was minimal donor site morbidity. Conclusion: The RRA flap is a useful, simple flap for defects around the elbow joint in select patients providing one stage, reliable, cosmetically acceptable coverage.

\section{KEY WORDS}

Local flap; posterior elbow defect; radial recurrent artery

\section{INTRODUCTION}

pen soft tissue defects around the elbow joint are commonly seen consequent to trauma, burns, release of post-burns contractures and internal fixation of complex fractures in this region. Such defects often result in the exposure of functionally important structures such as bone, tendon, blood vessels and nerves and thus require stable coverage. Reconstructive goals

\begin{tabular}{|l|l|}
\hline \multicolumn{2}{|c|}{ Access this article online } \\
\hline Quick Response Code: & Website: \\
\hline & www.ijps.org \\
\cline { 2 - 2 } & Dol: \\
\hline & $10.4103 / 0970-0358.197235$ \\
\hline
\end{tabular}

are to provide stable soft tissue cover of the exposed vital structure/hardware while allowing early mobilisation for preservation of the range of motion.

The choice of an appropriate flap needs to be based not only on the tissue availability, pliability and quality but also with due consideration of the patient's general condition.

This is an open access article distributed under the terms of the Creative Commons Attribution-NonCommercial-ShareAlike 3.0 License, which allows others to remix, tweak, and build upon the work non-commercially, as long as the author is credited and the new creations are licensed under the identical terms.

For reprints contact: reprints@medknow.com

How to cite this article: Devale MM, Munot RP, Bhansali CA, Bhaban ND. Awkward defects around the elbow: The radial recurrent artery flap revisited. Indian J Plast Surg 2016;49:357-61. 
While such defects can be managed with both local and free flaps, local flaps are generally preferred in view of shorter operating time and better cosmetic tissue match in terms of both colour and texture as compared to muscle flaps with skin graft.

In the region of the elbow joint, there are limited local axial flaps that can be performed and hence these defects pose a unique reconstructive challenge. The radial recurrent artery (RRA) flap is a versatile option for both anterior and posterior elbow defects.

The major advantages of the flap are:

- Consistent axial pedicle

- Ease of dissection

- Good cosmetic result as 'like is replaced with like'

- A short, one-stage procedure,

- No sacrifice of a major artery or local muscle, and

- Avoidance of any long-term immobilisation of the involved elbow joint. ${ }^{[1]}$

\section{Relevant anatomy}

The profunda brachii artery divides into the radial collateral artery (RCA) and middle collateral artery (MCA). The MCA runs through the intermuscular septum between the triceps posteriorly, and the brachialis and brachioradialis anteriorly. This artery supplies the overlying skin through numerous septocutaneous perforators (basis for the lateral arm flap). ${ }^{[2]}$

The RCA is mainly concerned with supplying the brachioradialis and the brachialis and radial nerve before anastomosing with the RRA in front of the lateral epicondyle [Figure-1].

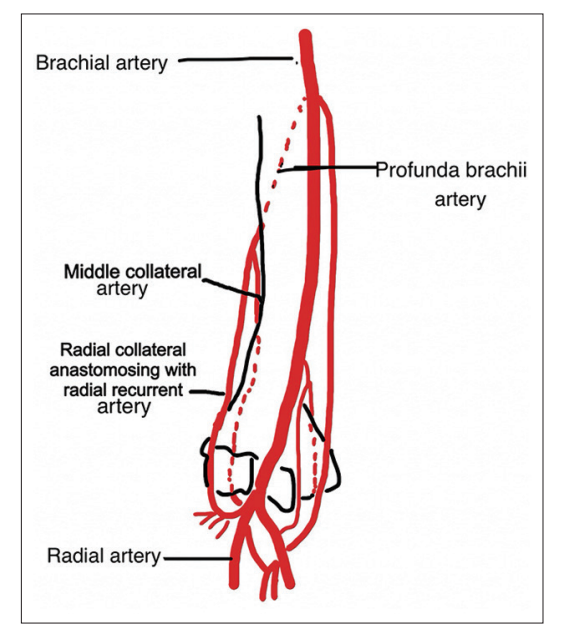

Figure 1: Arterial anatomy around elbow
The RRA arises most commonly from the radial artery (64\%), immediately below the elbow joint, or from distal part of the brachial artery (18\%). ${ }^{[3]}$ It ascends between the branches of the radial nerve, lying on the supinator and then between the brachioradialis and brachialis, supplying these muscles, extensor carpi radialis longus, extensor carpi radialis brevis and the elbow-joint, and anastomosing with the RCA. It supplies skin over part of lateral aspect of the arm. ${ }^{[2]}$

\section{MATERIALS AND METHODS}

A retrospective analysis of four cases operated at our institute from January 2015 to August 2016 was included in the study. All patients were males between the age group of 21-35 years (mean age was 31 years). All patients were referred to us after approximately around 1 month after the fractures were fixed through a posterior midline incision and after the plate/bone was exposed. No patients had distal neurovascular deficit and/or comorbidities. Three out of four patients had right sided defects. Smallest defect was $4 \mathrm{~cm} \times 4 \mathrm{~cm}$ and the largest was $7 \mathrm{~cm} \times 5 \mathrm{~cm}$ [Table 1].

The wound was debrided and the defect measured with the elbow in full flexion (if the implant had been removed). Then the defect was then covered with the flap. Mean operation time was $2 \mathrm{~h}$. The duration of follow-up was 2-18 months.

\section{Surgical technique}

The patient was positioned supine with the elbow flexed and forearm rested on the abdomen. Lateral epicondyle was marked. The signals from the RRA were identified and marked anterior to the lateral epicondyle. Flap base was marked $0.5 \mathrm{~cm}$ anterior and superior to lateral epicondyle. The axis of the flap was centred on a line joining the insertion of the deltoid and the lateral epicondyle which represents the intermuscular septum between triceps and brachialis. The flap was designed on this axis after planning in reverse.

Under loupe magnification, flap was raised in the subfascial plane after taking the posterior incision first. The deep fascia was included in the flap to make dissection of flap easy. Cranial part of the incision was then taken and the flap was raised, dividing the septum and leaving the RCA. Perforators of the RCA travelling in the septum were ligated as encountered. Dissection 
Table 1: Details of the defects

\begin{tabular}{|c|c|c|c|c|c|}
\hline Aetiology & Location of defect & $\begin{array}{c}\text { Size of } \\
\text { defect }(\mathrm{cm})\end{array}$ & $\begin{array}{c}\text { Flap } \\
\text { size }(\mathrm{cm})\end{array}$ & $\begin{array}{c}\text { Donor } \\
\text { area }\end{array}$ & Complications \\
\hline Post-traumatic (exposed hardware with bone) & Right posterior elbow & $4 \times 4$ & $6 \times 5$ & SSG & No \\
\hline Post-traumatic (exposed hardware with bone) & Left posterior elbow & $6 \times 4$ & $7 \times 7$ & SSG & No \\
\hline Post-traumatic (exposed bone) & Right posterior elbow & $7 \times 5$ & $9 \times 5$ & SSG & No \\
\hline Post-traumatic (exposed hardware and bone) & Right posterior elbow & $5 \times 5$ & $7 \times 6.5$ & SSG & No \\
\hline
\end{tabular}

SSG: Split skin grafting

continued distally towards the lateral epicondyle taking care not to damage the radial nerve. RCA was then ligated between $3 \mathrm{~cm}$ and $5 \mathrm{~cm}$ proximal to the lateral epicondyle and dissection continued over the periosteum. The recurrent radial artery travels in subcutaneous tissue close to the periosteum in the epicondylar region. We did not skeletonise the vessel. Few branches of the posterior cutaneous nerve of arm were sacrificed to facilitate the reach of flap. The flap base was narrowed to $1-1.5 \mathrm{~cm}$ after confirming exact position of the artery based on location of Doppler signals. The flap was rotated to the defect around $90-120^{\circ}$ as required by location of the defect and the donor site was skin grafted. A drain was placed under the flap. Upper limb was immobilised for 10 days till the flap and donor site healed.

\section{Observation}

All the flaps survived completely [Figures 2 and 3]. Flap donor site was covered with skin graft which healed uneventfully. No infection, hematoma or congestion was noted in any flap. Smallest flap in our series was $6 \mathrm{~cm} \times 5 \mathrm{~cm}$ whereas largest flap was $9 \mathrm{~cm} \times 5 \mathrm{~cm}$. During harvest of the flap, mean two perforators of RCA were clipped and RCA was ligated at a mean distance of $3.5 \mathrm{~cm}$ proximal to lateral epicondyle and flap dissection continued further till $0.5 \mathrm{~cm}$ proximal to lateral epicondyle.

Since the RCA enters the deep fascia, and is outside the 'axiality' of the flap, we decided to measure the 'random' element of the flap. These are the findings [Table 2].

\section{DISCUSSION}

Defects around the posterior elbow region can pose reconstructive challenges. Many techniques have been described which include local flaps, regional or distant pedicled flaps and free tissue transfer. Local flaps are few while distant flaps require multiple stages and long periods of immobilisation. ${ }^{[4]}$ Free flaps, best used for large defects, are not always suitable for elderly and debilitated patients..$^{[5]}$

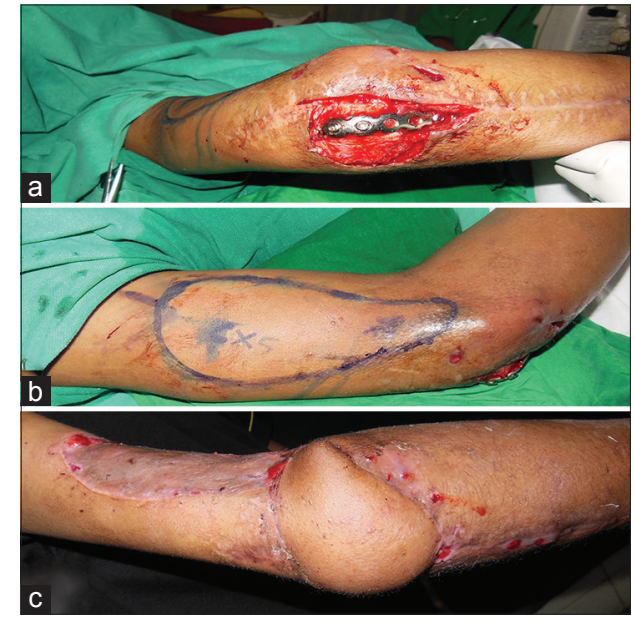

Figure 2: Case 1 (a) right elbow defect with exposed implant (b) design of the flap (c) well settled flap

Among local flaps [Table 3], flap based on MCA will not be available due to damage to perforators because of previous posterior midline incision. Radial forearm and ulnar artery forearm flap involve sacrificing a major artery of the forearm. ${ }^{[6]}$ All patients in our series had posterior midline incision extending mid arm to upper one-third of ulna which might have injured PIA. Proximally based posterior interosseous artery flap requires tedious dissection. ${ }^{[7]}$ The use of brachioradialis muscle flap can result in functional deficit in the absence of elbow flexors. ${ }^{[8]}$ Latissimus dorsi muscle flap requires intraoperative change of position of the patient, more dissection and hence longer operative time. It is also not very well suited for posterior defects including the olecranon region.

A similar flap, radial recurrent fasciocutaneous flap was described in a case series of two patients by Maruyama and Takeuchi in 1986. ${ }^{[9]}$ Although he has described it as reverse lateral arm flap, the vascular basis of the reverse lateral arm flap is perforators of MCA and its anastomosis with interosseous recurrent artery (IRA) and not RRA.

Also according to Maruyama and Takeuchi ${ }^{[9]}$ this flap is a modified Type B fasciocutaneous flap which is not the case, since anatomical studies by the same author have shown that it is an axial flap based on 
Table 2: Details of RRA flap

\begin{tabular}{lccc}
$\begin{array}{l}\text { Size of } \\
\text { flap }(\mathbf{c m})\end{array}$ & $\begin{array}{c}\text { Site of clipping of RCA proximal } \\
\text { to lateral epicondyle }(\mathbf{c m})\end{array}$ & $\begin{array}{c}\text { Size of flap beyond } \\
\text { clipping of } R \text { CA }(\mathbf{c m})\end{array}$ & $\begin{array}{c}\text { Number of perforators } \\
\text { of RCA clipped }\end{array}$ \\
\hline $6 \times 5$ & 3 & $3 \times 5$ & 2 \\
$7 \times 7$ & 3.5 & $3.5 \times 7$ & 2 \\
$9 \times 5$ & 4 & $5 \times 5$ & 3 \\
$7 \times 6.5$ & 3.5 & $3.5 \times 6.5$ & 1 \\
\hline
\end{tabular}

RCA: Radial collateral artery

Table 3: Analysis of flaps for posterior elbow defects

\begin{tabular}{|c|c|c|}
\hline Flap & Pros & Cons \\
\hline $\begin{array}{l}\text { Radial forearm } \\
\text { flap and ulnar } \\
\text { artery flap }\end{array}$ & $\begin{array}{l}\text { Reliable } \\
\text { Ease of dissection }\end{array}$ & $\begin{array}{l}\text { Sacrifice of major } \\
\text { vessel }\end{array}$ \\
\hline $\begin{array}{l}\text { Posterior } \\
\text { interosseous } \\
\text { artery flap }\end{array}$ & $\begin{array}{l}\text { No sacrifice of major } \\
\text { vessel } \\
\text { Same operative field }\end{array}$ & $\begin{array}{l}\text { Tedious dissection } \\
\text { Useful for only small } \\
\text { defects }\end{array}$ \\
\hline $\begin{array}{l}\text { Brachioradialis } \\
\text { flap }\end{array}$ & $\begin{array}{l}\text { No sacrifice of major } \\
\text { vessel }\end{array}$ & $\begin{array}{l}\text { Useful for small defects } \\
\text { May lead to loss of } \\
\text { elbow flexion }\end{array}$ \\
\hline $\begin{array}{l}\text { Latissimusdorsi } \\
\text { flap }\end{array}$ & $\begin{array}{l}\text { Wider defects can } \\
\text { be covered }\end{array}$ & $\begin{array}{l}\text { Change of position } \\
\text { required }\end{array}$ \\
\hline
\end{tabular}

direct communication/continuation between RCA and RRA at a point approximately $3.5 \mathrm{~cm}$ above the lateral epicondyle (range $1.5-6.5 \mathrm{~cm}$ ) by a vessel approximately $0.3 \mathrm{~mm}$ in two-third of cases. In the remaining one-third of cases, the anastomosis is by multiple very fine vessels not visible to the naked eye. ${ }^{[10]}$ Hence, an appropriate terminology for this flap may be the RRA flap. Although we have safely elevated a $9 \mathrm{~cm} \times 5 \mathrm{~cm}$ flap, precise dimensions of the flap can only be confirmed by further vascular studies.

In our flap, RCA was included only after it passed through the deep fascia and became superficial, to anastomose with the RRA. Although pre-operative angiogram has been recommended, ${ }^{[11]}$ especially if vascular injury is associated with such defects, all our patients had no neurovascular deficit. Hence, no pre-operative angiogram was done.

The mean dimensions of the flap territory beyond the clipping of the RCA were $3.7 \mathrm{~cm}$ in length and $5.9 \mathrm{~cm}$ in width. We presume this territory of flap after clipping of the vessel may be a random extension of the flap, especially since all the perforators from the RCA were clipped subfascially. There could be an arborisation of vessels continuing from RRA, which might perfuse this territory, however, this will need further confirmation with vascular studies. Similarly, we cannot draw any correlation with the number of perforators ligated and the size of the random element.

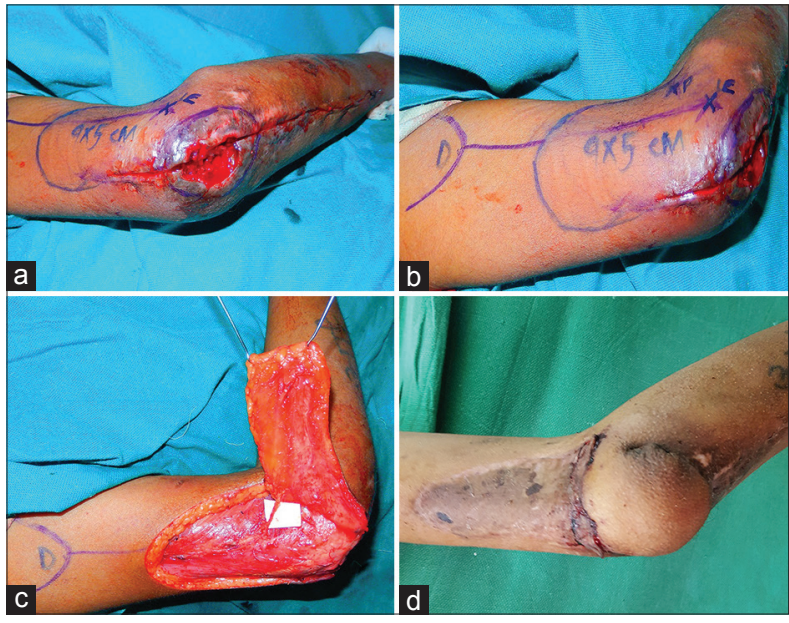

Figure 3: Case 2 (a) right elbow defect with exposed bone (b) design of the flap (c) branch of posterior cutaneous nerve of arm which requires transection (d) well settled flap and donor site

In the posterior elbow defects, the anastomosis between $\mathrm{RRA}$ and $\mathrm{RCA}^{[10]}$ which is located anterior to the lateral epicondyle is usually well preserved and hence the flap can be safely harvested even if the posterior midline incision has been taken for fracture fixation.

The flap is harvested in supine position and does not require intraoperative change of position. Flap dissection is relatively easy. Cutaneous braches of nerve supplying the skin of the flap are cut during the harvest of flap. Although the flap per se was insensate, there was no sensory deficit anywhere else, including distally.

There is no associated functional impairment and no major vessel is sacrificed. The surgical technique is comparatively simple and can be performed in regional anaesthesia. Post-operative recovery is short. Early mobilisation of the elbow joint is feasible.

Morrison et al. chose to delay this flap for complex post-traumatic elbow defects. ${ }^{[12]}$ In our series, we performed one stage reconstruction in all our patients. We did not encounter any venous congestion leading to flap failure. We also believe, that as the base of the flap is located anterior to the lateral epicondyle there is less 
chance of kinking and venous engorgement as compared to the flap based on the IRA, which was postulated by Culbertson and Mutimer. ${ }^{[13]}$

\section{CONCLUSION}

The RRA flap is a useful, simple flap for defects around the elbow joint in select patients providing one stage, reliable, cosmetically acceptable coverage with minimal donor site morbidity.

\section{Acknowledgement}

The authors would like to thank Dr. Mukund Jagannathan Professor and headDepartment of PlasticSurgery, Lokmanya Tilak Medical College, Sion, Mumbai, Maharashtra, India.

\section{Financial support and sponsorship}

Nil.

\section{Conflicts of interest}

There are no conflicts of interest.

\section{REFERENCES}

1. Lai CS, Tsai CC, Liao KB, Lin SD. The reverse lateral arm adipofascial flap for elbow coverage. Ann Plast
Surg 1997;39:196-200

2. Cormack GC, Lamberty BG. Fasciocutaneous vessels in the upper arm: Application to the design of new fasciocutaneous flaps. Plast Reconstr Surg 1984;74:244-50.

3. Coessens B, Vico P, De Mey A. Clinical experience with the reverse lateral arm flap in soft-tissue coverage of the elbow. Plast Reconstr Surg 1993;92:1133-6.

4. Fisher J. External oblique fasciocutaneous flap for elbow coverage. Plast Reconstr Surg 1985;75:51-61.

5. Ikuta Y, Watari S, Kawamura K, Shima R, Matsuishi Y. Free flap transfers by end-to-side arterial anastomosis. $\mathrm{Br} \mathrm{J}$ Plast Surg 1975;28:1-7.

6. Kleinman WB, O'Connell SJ. Effects of the fasciocutaneous radial forearm flap on vascularity of the hand. J Hand Surg Am 1993;18:953-8.

7. Balakrishnan G, Kumar BS, Hussain SA. Reverse-flow posterior interosseous artery flap revisited. Plast Reconstr Surg 2003;111:2364-9.

8. Gilbert A, Restrepo J. The brachioradial muscle: Anatomy and use as a muscular rotation flap. Ann Chir Plast 1980;25:72-5.

9. Maruyama $\mathrm{Y}$, Takeuchi $\mathrm{S}$. The radial recurrent fasciocutaneous flap: Reverse upper arm flap. Br J Plast Surg 1986;39:458-61.

10. Hayashi A, Maruyama Y. Anatomical study of the recurrent flaps of the upper arm. Br J Plast Surg 1990;43:300-6.

11. Tung TC, Wang KC, Fang CM, Lee CM. Reverse pedicled lateral arm flap for reconstruction of posterior soft-tissue defects of the elbow. Ann Plast Surg 1997;38:635-41.

12. Morrison CS, Sullivan SR, Bhatt RA, Chang JT, Taylor HO. The pedicled reverse-flow lateral arm flap for coverage of complex traumatic elbow injuries. Ann Plast Surg 2013;71:37-9.

13. Culbertson $\mathrm{JH}$, Mutimer $\mathrm{K}$. The reverse lateral upper arm flap for elbow coverage. Ann Plast Surg 1987;18:62-8. 